
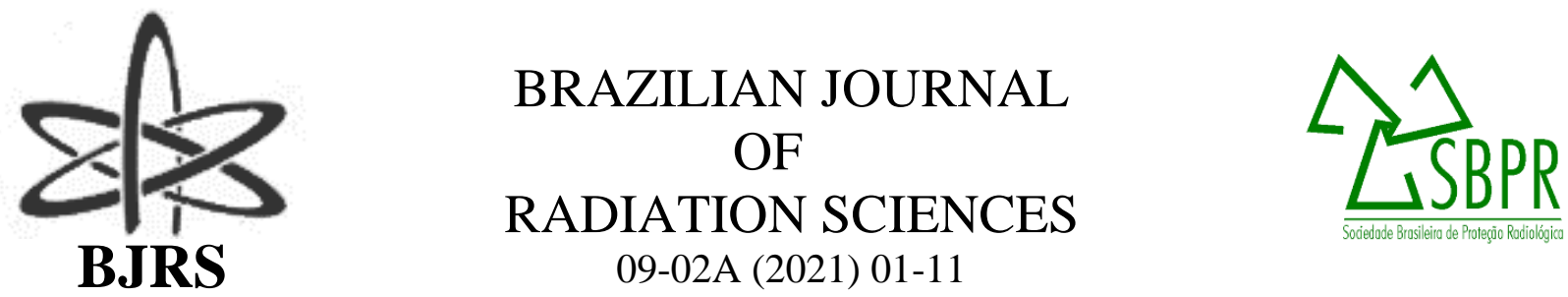

\title{
Quantification of effluents in the production of nuclear fuel
}

\author{
M. C. C. B. Sakai; H. G. Riella; E. F. U. Carvalho \\ Instituto de Pesquisas Energéticas e Nucleares, Comissão Nacional de Energia Nuclear (IPEN / CNEN - SP), \\ Av. Professor Lineu Prestes 2242, 05508-000, São Paulo, SP, Brazil \\ mayaracdecastro@gmail.com
}

\begin{abstract}
The Brazil with the purpose of becoming self-sufficient in the production of radioisotopes and radioactive sources used in nuclear medicine, agriculture and the environment developed the project of a multipurpose reactor of 30 megawatts of power to attend the national demand. In the Nuclear and Energy Research Institute (IPEN), Nuclear Fuel Center (CCN) is responsible for the manufacture of fuel for the reactor IEA-R1 and, possibly, the multipurpose reactor fuels. In order to meet the demand for the reactors was designed a new manufacturing plant with a maximum capacity of 60 fuel elements, which is 10 nowadays. The increase in production as a consequence will increase the volume of effluents generated. The current concern with the environment it is necessary to draw up a management plan to make the process sustainable, which will result in environmental, economic and social benefits. The fuel production process generates various types of effluent containing uranium or not - being solid, gaseous and liquid with different physical and chemical characteristics. The aim of this work is to follow the process of nuclear fuel production and to identify, quantify and characterize the effluents, especially liquids, to subsequently draw up a management plan and eventually dispose of responsibly in the environment.
\end{abstract}

Keywords: wastewater, fuel cycle, nuclear fuel, uranium. 


\section{INTRODUCTION}

For many years, the IPEN worked in the development of the manufacturing process of fuel elements used internationally in research reactors to the nationalization of your production for use in your reactor IEA-R1. Since your inauguration in 1956 and for almost three decades, over a time of uncertainty about the market in nuclear materials, the IEA-R1 reactor depended entirely on the import of fuel elements required for your operation, which are supplied by GENERAL ATOMICS ( 93\% 235U) and NUKEM (20\% 235U) [1].

Considering the social and strategic importance of the production of radiopharmaceuticals in the country and the continued growth of expenditure on importation of radioisotopes needed to meet this production the Ministry of Science, Technology, and Innovation has established as a goal in your Action Plan in 2007 [2] the construction of a multipurpose reactor, with the intention of becoming self-sufficient in the production of radiopharmaceuticals.

Currently, more than 1.5 million procedures are performed involving radiopharmaceuticals in Brazil. Radiopharmaceuticals are substances that emit radiation and are used mainly in medicine for treatment and diagnostic imaging. Most radioisotopes, which are the active elements of radiopharmaceuticals, are imported generating an expense of at least $\$ 30$ million per year.

This determined the need for implementation of a new production unit in the Center of Nuclear Fuel (CCN), planned for use in the manufacture $\mathrm{U}_{3} \mathrm{Si}_{2}$ of fuel elements [3]. This new facility was designed to expand the current capacity of MTR-type fuel elements (Material Testing Reactor-fuel dispersion-based plan).

The new reactor called Brazilian Multipurpose Reactor (RMB), which will be built with 30 megawatts of power, has three main functions: providing radioisotopes for use in health, industry, environment and agriculture; build national capacity to test and qualify materials and nuclear fuels and facilitate the installation of a national research lab with neutron beams [2].

The CCN, located at IPEN, about 30 years is the only national provider of fuel for research reactors. So, will be responsible for the manufacturing of nuclear fuel to this new reactor. The current capacity of the $\mathrm{CCN}$ is about ten fuel elements, to attend the new demand was designed a plant that will allow the maximum production of 60 fuels elements. 
The new facility will operate in an integrated mode, in which all the manufacturing activities will be carried out under a more coherent plan, having its origin in the conversion of $\mathrm{UF}_{6}$ to the final assembly of the fuel element.

The fuel element production generates various types effluents (containing uranium or not) with different physical and chemical characteristics. These effluents should be treated, recovered and should return to the productive process.

With all this concern for the environment, standards emerge in order to inspect the business and reduce impacts on the environment. But, over the years, the business concern with fines and notices in relation to the laws is no longer a priority, being replaced by greater care for the company's image.

It was in this context that developed environmental management, a set of actions that involve public policies, the productive sector, and society in order to encourage the rational and sustainable use of environmental resources. It is a process that connects the issues of preservation and development at all levels.

Considering the historical evolution of the concern with the environment until the moment of development of environmental management, this work aims to make the CCN of IPEN be able to manage and control its effluents generated in the fuel production process nuclear. Therefore, the objective of this work is to accompany the nuclear fuel production process and to identify, quantify and characterize the effluents, mainly liquids, to later draw up a management plan and eventually dispose of it in a responsible manner in the environment.

\section{MATERIALS AND METHODS}

For the development of this work, studies were carried out and the following steps were established:

a) Evaluate and analysis of current environmental legislation in the country;

b) Processes flow analysis produced;

c) Collection of samples of effluents generated; 
d) Characterization of all effluents (liquid and solid) and conventional radioactive generated during the manufacturing process of fuel elements, taking into account the physical parameters and specific contaminants;

e) Qualitative and quantitative evaluate of effluents produced;

f) Evaluate of the impact considerations of such waste and effluents generates on the environment;

g) Evaluation and definition of the segregation of wastewater in order to group the ones that require the same treatment, separating them from that require specific treatments.

\section{RESULTS AND DISCUSSION}

This work was developed through the monitoring of the fuel element production process at the $\mathrm{CCN}$, which made it possible to indicate the types of effluents generated in each stage. The production of nuclear fuel has as its product liquid, gaseous, solid effluents. As the focus of this work is liquid effluents, Figure 1 shows the liquid effluents generated in the nuclear fuel production process.

Figure 1: Effluents generated in the process of production of nuclear fuel.

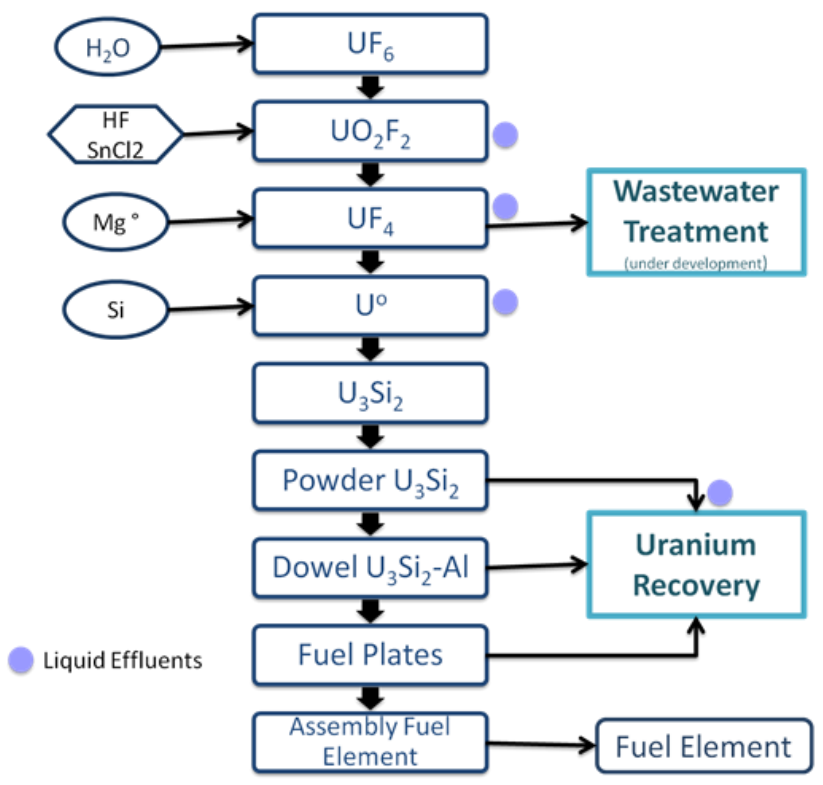


For more detailed results, the Table 1 shows the three sectors of the CCN associated to the stages of the production process of the fuel element and its effluents generated, and even if the effluents are radioactive.

Table 1: Liquid effluents generated in the production of fuel element.

\begin{tabular}{|c|c|c|}
\hline Sector & Process Steps & Effluents \\
\hline \multirow{8}{*}{$\begin{array}{l}\text { Chemical } \\
\text { Processing }\end{array}$} & \multirow{2}{*}{ Conversion of $\mathrm{UF}_{6}$} & Effluent $\mathrm{UF}_{4}$ \\
\hline & & Water Reduction Crystallization \\
\hline & \multirow{3}{*}{ Uranium recovery } & Effluent DUA \\
\hline & & Organic Solution \\
\hline & & Sodium Aluminate solution \\
\hline & \multirow{3}{*}{$\begin{array}{l}\text { Treatment of industrial } \\
\text { effluents }\end{array}$} & Water from gas scrubbers \\
\hline & & Acid solution (analysis on CQMA) \\
\hline & & $\begin{array}{l}\text { Aqueous solution (emergency sys- } \\
\text { tem) }\end{array}$ \\
\hline \multirow{3}{*}{$\begin{array}{l}\text { Special Alloys } \\
\text { Processing }\end{array}$} & \multirow{3}{*}{$\begin{array}{l}\text { Reduction and melting of } \\
\text { Alloys }\end{array}$} & Acid solution (pickling $\mathrm{U}^{\circ}$ ) \\
\hline & & Aqueous Solution (Pickling Uº \\
\hline & & Alcohol solution \\
\hline \multirow{4}{*}{$\begin{array}{l}\text { Mechanical and } \\
\text { Metallurgical } \\
\text { Processing }\end{array}$} & $\begin{array}{l}\text { Post processing and Bri- } \\
\text { quettes }\end{array}$ & Solution Nitric \\
\hline & \multirow{2}{*}{$\begin{array}{l}\text { Manufacture of plates and } \\
\text { mounting of the EC }\end{array}$} & $\begin{array}{l}\text { Nitric Acid solution (stripping } \\
\text { plates) }\end{array}$ \\
\hline & & $\begin{array}{l}\text { Sodium hydroxide solution (stripping } \\
\text { plates) }\end{array}$ \\
\hline & $\begin{array}{l}\text { Metrology and process } \\
\text { control }\end{array}$ & $\begin{array}{l}\text { Aqueous solution (metallographic } \\
\text { analysis) }\end{array}$ \\
\hline
\end{tabular}

Radioactive effluents

In Table 2 shows the liquid effluents generated in the process of production of nuclear fuel, the amount that is produced, your respective chemical profiling and the treatment to which it is subjected. 


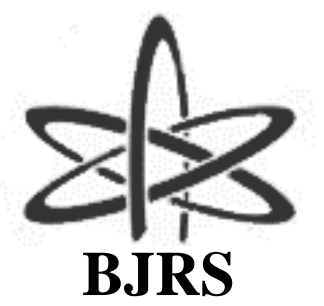

\section{BRAZILIAN JOURNAL $\bigcirc$ \\ OF \\ 09-02A (2021) 01-11}

Table 2: Liquid effluents generated in the production process of the fuel element.

\begin{tabular}{|c|c|c|c|c|}
\hline Item & Effluent & Quantity & Characterization & Treatment \\
\hline $\mathbf{A}$ & Effluent $\mathrm{UF}_{4}$ & $\begin{array}{l}40 \text { liters per boat- } \\
\text { load of EC }\end{array}$ & $\begin{array}{c}{\left[\mathrm{U}^{+6}\right]=0.12 \mathrm{~kg} \cdot \mathrm{m}^{-3}} \\
{\left[\mathrm{Sn}^{+2}\right]=20 \mathrm{~kg} \cdot \mathrm{m}^{-3}} \\
{\left[\mathrm{~F}^{-}\right]=0.047 \mathrm{~kg} \cdot \mathrm{m}^{-3}} \\
{\left[\mathrm{Cl}^{-}\right]=0.012 \mathrm{~kg} \cdot \mathrm{m}^{-3}} \\
\text { pH } 2.43\end{array}$ & In development. \\
\hline B & $\begin{array}{l}\text { Acid Solution } \\
\left(\text { Pickling } U^{\circ}\right)\end{array}$ & $\begin{array}{l}300 \mathrm{ml} \text { for each } \\
\text { etching. } \\
\mathrm{HNO}_{3} \text { pure }\end{array}$ & {$\left[\mathrm{U}^{+6}\right]<2.3 \mathrm{~g} \cdot \mathrm{m}^{-3}$} & $\begin{array}{l}\text { Precipitate as DUA. Calcined to } \\
\mathrm{UO}_{3} \text {. Returns the production line as } \\
\mathrm{UF}_{4} \text {. }\end{array}$ \\
\hline $\mathbf{C}$ & $\begin{array}{l}\text { Aqueous Solution } \\
\left(\text { Pickling } U^{\circ}\right)\end{array}$ & $\begin{array}{l}300 \mathrm{ml} \text { for each } \\
\text { etching }\end{array}$ & {$\left[\mathrm{U}^{+6}\right]<0.5 \mathrm{~g} \cdot \mathrm{m}^{-3}$} & $\begin{array}{l}\text { Discard after radiological environmen- } \\
\text { tal protection authorized after analysis } \\
\text { of the uranium content and in accord- } \\
\text { ance with the CONAMA } \mathrm{N}^{\circ} 20 \text {. }\end{array}$ \\
\hline D & $\begin{array}{l}\text { Alcohol from the superfi- } \\
\text { cial treatment of }{ }_{3} \mathrm{U} \mathrm{S}_{\mathrm{i} 2}\end{array}$ & 20 L/fuel Element & - & $\begin{array}{l}\text { Reused as technical alcohol in the pro- } \\
\text { duction facilities of the CCN. }\end{array}$ \\
\hline
\end{tabular}

ISSN: 2319-0612

Accepted: 2021-04-01 


\begin{tabular}{|c|c|c|c|c|}
\hline $\mathbf{E}$ & $\begin{array}{l}\text { Aqueous solution from } \\
\text { washings of granulo- } \\
\text { metric sieves and/or } \\
\text { equipment used in the } \\
\text { production process }\end{array}$ & $\begin{array}{l}0.5 \mathrm{~L} \text { every EC } \\
\text { produced }\end{array}$ & pH 6.7 & $\begin{array}{l}\text { Decantation of the uranium powder. } \\
\text { Separation of the supernatant. } \\
\text { Control of the levels of uranium. Dis- } \\
\text { card after radiological environmental } \\
\text { protection authorized, in accordance } \\
\text { with the CONAMA } N^{\circ} 20 \text {. }\end{array}$ \\
\hline $\mathbf{F}$ & $\begin{array}{l}\text { Nitric acid solution from } \\
\text { the pickling process of } \\
\text { fuel cards }\end{array}$ & $\mathrm{HNO}_{3} 30 \%$ & pH 3 & $\begin{array}{l}\text { The solution is sent to the CCR to reuse } \\
\text { in cleaning and decontamination of } \\
\text { reactors, filters, dissolution of uranium } \\
\text { (uranium recovery). }\end{array}$ \\
\hline G & $\begin{array}{l}\text { Sodium hydroxide solu- } \\
\text { tion from the pickling } \\
\text { process of fuel cards }\end{array}$ & $\begin{array}{l}30 \mathrm{~L} \text { of } 2,5 \mathrm{~m} \\
\mathrm{NaOH}\end{array}$ & $\mathrm{pH} 6$ & $\begin{array}{l}\text { The solution is sent to the CCR to re- } \\
\text { used in the process of dissolution of } \\
\text { fuel cards (uranium recovery). }\end{array}$ \\
\hline $\mathbf{H}$ & Effluent DUA & $200 \mathrm{~L} / 10$ plates & $\begin{array}{c}{\left[\mathrm{U}^{+6}\right]=8.5 \pm 1.5 \mathrm{~g} \cdot \mathrm{m}^{-3}} \\
{\left[\mathrm{NH}_{4}^{+}\right]=8.8 \pm 0.8 \mathrm{~kg} \cdot \mathrm{m}^{-3}} \\
{\left[\mathrm{~F}^{-}\right]=69 \pm 1.8 \mathrm{~kg} \cdot \mathrm{m}^{-3}} \\
\text { pH } 9.2\end{array}$ & $\begin{array}{l}\text { Ion exchange and the uranium recov- } \\
\text { ered with uranyl carbonate. }\end{array}$ \\
\hline I & $\begin{array}{l}\text { Aqueous solution from } \\
\text { uranium recovery }\end{array}$ & $\begin{array}{l}15 \mathrm{~L} \text { per batch } / 10 \\
\text { plates }\end{array}$ & {$\left[\mathrm{U}^{+6}\right]=1.96 \pm 0.12 \mathrm{~g} \cdot \mathrm{m}^{-3}$} & $\begin{array}{l}\text { Analysis and Disposal in accordance } \\
\text { with the CONAMA } \mathrm{N}^{\circ} 20 \text {. }\end{array}$ \\
\hline $\mathbf{J}$ & $\begin{array}{l}\text { Organic solution from } \\
\text { uranium r recovery } \\
\text { (TBP/isoparafina) }\end{array}$ & $\begin{array}{l}15 \mathrm{~L} \text { per batch } / 10 \\
\text { plates }\end{array}$ & $\begin{array}{l}{\left[\mathrm{U}^{+6}\right]=97.7 \pm 0.5 \mathrm{~g} \cdot \mathrm{m}^{-3}} \\
{\left[\mathrm{U}^{+6}\right]=10.2 \pm 0.3 \mathrm{~g} \cdot \mathrm{m}^{-3}}\end{array}$ & $\begin{array}{l}\text { Wash with sodium carbonate. } \\
\text { Wash with } \mathrm{HNO}_{3} \text {. } \\
\text { Wash with water until the pH } 7 . \\
\text { Wash with } \mathrm{HNO}_{3} 3 \mathrm{M} . \\
\sim 100 \text { L: stocked. }\end{array}$ \\
\hline
\end{tabular}




\begin{tabular}{|c|c|c|c|c|}
\hline $\mathbf{K}$ & $\begin{array}{l}\text { Acid solution from chem- } \\
\text { ical analysis performed } \\
\text { on the fuel control } \\
\text { CQMA and returned to } \\
\text { CCN }\end{array}$ & $\begin{array}{l}\text { Every } 3 \text { months of } \\
\text { production gener- } \\
\text { ates } 5 \mathrm{~L} \text { of purified } \\
\text { uranium solution }\end{array}$ & $\begin{array}{c}{\left[\mathrm{U}^{+6}\right]=15 \mathrm{~g} \cdot \mathrm{m}^{-3}} \\
{\left[3^{-}\right]=80 \mathrm{~g} \cdot \mathrm{m}^{-3}}\end{array}$ & $\begin{array}{l}\text { Precipitate as DUA. Calcined to } \\
\mathrm{UO}_{3} \text {. Returns the production line as } \\
\mathrm{UF}_{4} \text {. }\end{array}$ \\
\hline $\mathbf{L}$ & $\begin{array}{l}\text { Aqueous solution from } \\
\text { the system of emergency } \\
\text { showers and eyewashes }\end{array}$ & - & $\begin{array}{l}\text { Does not apply, because so } \\
\text { far there was no need to use } \\
\text { the emergency system }\end{array}$ & $\begin{array}{l}\text { Disposed of according to environmen- } \\
\text { tal radiological protection after urani- } \\
\text { um content analysis as the CONAMA } \\
20 \text {. }\end{array}$ \\
\hline $\mathbf{M}$ & $\begin{array}{l}\text { Aqueous solution gener- } \\
\text { ated in the metallographic } \\
\text { analyses }\end{array}$ & $\begin{array}{l}\text { Solution stored in a } \\
20001 \text { tank }\end{array}$ & $\begin{array}{l}{\left[3^{-2}\right]=0.24 \mathrm{~g} \cdot \mathrm{m}^{-3}} \\
{\left[\mathrm{~F}^{-}\right]=0.38 \mathrm{~g} \cdot \mathrm{m}^{-3}}\end{array}$ & $\begin{array}{l}\text { Disposed of according to environmen- } \\
\text { tal Radiological protection after analy- } \\
\text { sis of uranium content, activity and } \mathrm{pH} \\
\text { (CONAMA 20). }\end{array}$ \\
\hline $\mathbf{N}$ & $\begin{array}{l}\text { Sodium aluminate from } \\
\text { the dissolution of fuel } \\
\text { cards }\end{array}$ & 60-80 L/batch & $\begin{array}{l}{\left[\mathrm{U}^{+6}\right]=18 \mathrm{~g} \cdot \mathrm{m}^{-3}} \\
{\left[\mathrm{Na}^{+}\right]=24 \mathrm{~g} \cdot \mathrm{m}^{-3}} \\
{\left[\mathrm{Al}^{-}\right]=38 \mathrm{~kg} \cdot \mathrm{m}^{-3}}\end{array}$ & In development. \\
\hline
\end{tabular}



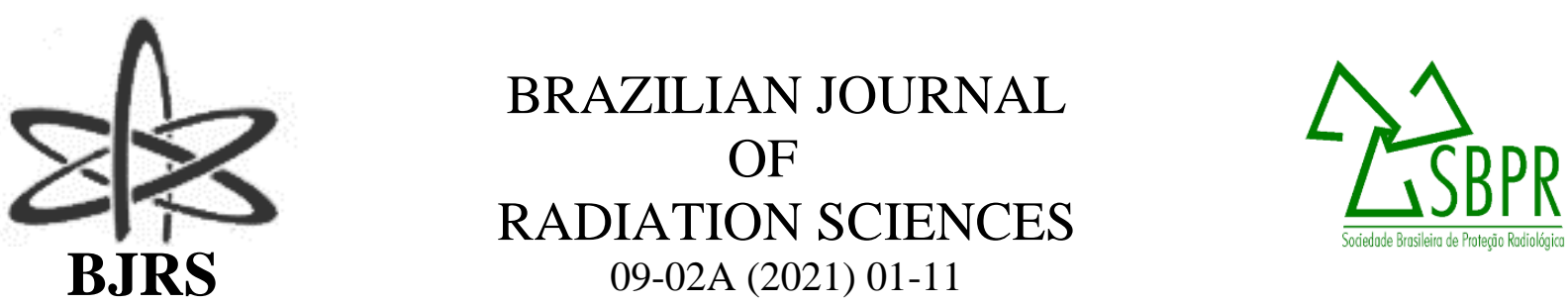

The waste originated in the productive areas of the $\mathrm{CCN}$ is collected in the place of origin then segregated according to the physical state and chemical composition. During the time of collecting these containers are kept in plastic holders identified and subsequently sent for recycling.

Currently at the $\mathrm{CCN}$, liquid effluents are divided into two classes: radioactive and conventional effluents. According to the classification adopted, radioactive waste is collected and sent to uranium treatment and recovery and conventional liquid effluents are sent to temporary storage in tanks, before allocation to the local storage or treatment area. Liquid effluent storage tanks are confined to polyethylene containment tanks.

The wastewater identified as items B and K can be segregated for treatment and recovery of uranium and fluoride because they have similar chemical characteristics. It should be noted that the mass of enriched uranium must be between $19.75 \pm 0.20 \%$ concentration by weight, to avoid criticality problems. CCN administrative procedures establish the safe handling of mass processing.

The effluents generated in the fuel plates such as pickling solution of nitric acid (F) and (G) $\mathrm{NaOH}$ solution is reused in the production process. The solution of nitric acid is used to dissolve uranium power and slags doing only the concentration setting. The solution can also be used in the cleaning and decontamination of chemical reactors, filters, etc.

The $\mathrm{NaOH}$ solution follows the same procedure, being utilized in the processing and recovery of fuel plates and in the dissolution of aluminum. Before use, an analysis is performed to check the $\mathrm{NaOH}$ concentration, and after $\mathrm{pH}$ correction the solution is ready for use.

Alcohol, item D, used for drying of the fuel plates in the pickling process is also reused in production unit as "alcohol". Other technologies can be applied, but are not yet in the CCN.

Some effluents are still in the development stage, among them the effluent of $\mathrm{UF}_{4}$, the development of which involves besides uranium recovery the return to the productive process. So far studied the recovery of fluoride in the form of Fluorite $\left(\mathrm{CaF}_{2}\right)$ which then can be used in step for the production of uranium metal. For the recovery of Tin analyze the feasibility of using ammonium carbonate $\left(\mathrm{NH}_{3} \mathrm{CO}_{2}\right)$.

The only organic sewage generated in the process is a result of uranium purification step, the tributyl phosphate (TBP). This effluent is treated chemically and reused in the purification process 
for another 4 batch of 10 more fuel plates. After this it becomes radioactive tailings with uranium concentration of $10 \mu \mathrm{g} \mathrm{U} . \mathrm{mL}-1$.

\section{CONCLUSION}

According to the results, it was possible to conclude that:

The nuclear field is a very broad field of research in all its aspects. In the environmental aspect, the characterization of the effluents generated in the production process of the nuclear fuel type MTR allowed to know better the contaminating load, being the main uranium, fluoride and ammonia.

The process of controlling liquid effluents is relevant, being possible to carry out treatment, and when meeting the required compliance, it is possible to dispose or recover the uranium back into the process.

It is known that $30 \%$ of liquid effluents are recovered from uranium, which return to the production process and the waste generated receives conventional treatment. $20 \%$ of the liquid effluents are reused in the chemical composition in which they were generated, 35\% of which are directly discharged into the environment in accordance with the legislation. The rest of the effluents, around $15 \%$, are in the process of developing the treatment process.

\section{ACKNOWLEDGMENT}

The authors wish to express your gratitude to the CAPES Foundation, Ministry of Education, by providing financial support for this work through the CAPES/ELETRONUCLEAR 012/2013.

The authors also thank the support received from IPEN. 


\section{REFERENCES}

[1] DURAZZO, M., CARVAlhO, E. F. U., Silva A, M. S., SOUZA, J. A. B.; RIELlA H, G. Fabricação de elementos combustíveis a base de $\mathrm{U}_{3} \mathrm{Si}_{2}$ no Brasil. Revista Brasileira de Pesquisa e Desenvolvimento, v.9, n.1 p.18-28, 2007.

[2] Ministério da Ciência e da Tecnologia. Ciência, Tecnologia e Inovação para o Desenvolvimento Nacional - Plano de ação. Brasília, 2007-2010.

[3] IPEN, INSTITUTO DE PESQUISAS ENERGÉTICAS E NUCLEARES. Descrição das Atividades e Operações - Centro do Combustível Nuclear (CCN), Relatório Interno, São Paulo, 2007.

[4] MATTOS, L. A. T. Proposta metodológica para a identificação e avaliação de aspectos e impactos ambientais em instalações nucleares do IPEN: estudo de caso aplicado ao centro do Combustível Nuclear. Tese (Doutorado), Instituto de Pesquisas Energéticas e Nucleares / Universidade de São Paulo, São Paulo, 2008.

[5] BRASIL, Resolução CONAMA n 357, de 18/03/2005.Classificação dos corpos de água e diretrizes ambientais. Publicação DOU no $357 . \quad$ p.58-63, 2005.

[6] BRASIL, Resolução CONAMA n 430, de 13 de maio de 2011, Condições e padrões de lançamento de efluentes. Publicação DOU no 430, 2005. 